\title{
Induced Fe-Deficiency-Chlorosis Severity in Soybean using EDTA-Buffered Nutrient Solutions
}

\author{
A. Elgharably \\ Soils and Water Department, Faculty of Agriculture, Assiut \\ University, Assiut, Egypt.
}

\begin{abstract}
HELATOR-buffered nutrient solutions have been used to control Fe phytoavailability for dicots in a number of studies, but use of diethylenetriaminepentaacetic acid (DTPA) required adding $\mathrm{Zn}, \mathrm{Cu}$ and other trace elements at levels much higher than traditional nutrient solutions. In order to have lower levels of other trace element cations in the buffered solutions, ethylenediaminetetraacetic acid (EDTA) was used to impose varied levels of Fe stress to soybean (Glycine max L.Merr., cv Williams-82). In addition to a control treatment (no FeEDTA added), FeEDTA was supplied at 0.32, 1.00, 3.16, 5.00, 10.0, 20.0 and $50.0 \mu \mathrm{M}$ in $\mathrm{pH}$ buffered 0.5 Johnson solutions. Enough EDTA was added to chelate all of the micronutrient cations plus 100 $\mu \mathrm{M}$ of "excess" EDTA which is largely chelated with some of the $\mathrm{Ca}^{2+}$ in the nutrient solution. Plant dry matter significantly corresponded with Fe activity in solution. Highest dry matter was obtained with 20 and $50 \mu \mathrm{M} \mathrm{Fe}$ (plants remained green throughout the experiment). At intermediate levels (1-10 $\mu \mathrm{M}$ FeEDTA) plants had mild or moderate chlorosis and remained at a steady chlorosis rating until harvest. Over time, the leaves with 0 and $0.32 \mu \mathrm{M}$ FeEDTA became severely chlorotic. Analysis showed that trifoliolate leaf Fe corresponded with chlorosis severity, while all other microelements were present at normal concentrations of healthy soybeans, although somewhat increased due to smaller biomass dilution. The EDTA-buffered Johnson solution offers a strong control of Fe stress at varied severity and should provide a valuable tool in study of microelement plant nutrition.
\end{abstract}

Claims have been made that spray application of glyphosate may interfere with plant's ability to obtain soil Mn and Fe (e.g., Bernards et al., 2005, Bott et al., 2008, Eker et al., 2006, Huber, 2007, Huber et al., 2004 and Ozturk et al., 2008). Although the bulk of evidence refutes this claim for glyphosate-resistant (GR) genotypes (Ebelhar et al., 2006 and Duke et al., 2012), non-GR genotypes may suffer Fe or Mn deficiency because glyphosate is translocated to roots and root physiological adaptations are important in obtaining soil Fe and Mn (e.g., Ozturk et al., 2008). To date, there appear to be no controlled experiments testing this hypothesis which involved cultivars resistant to $\mathrm{Fe}$ or Mn deficiency grown on soils which are likely to induce Fe or Mn deficiency. The present study was conducted to establish a test system with controlled intermediate deficiency to allow testing any of effect of glyphosate on plant adaptation to low Fe supply. 
Nutrient solution tests of whether glyphosate interferes with plant processes to obtain soil $\mathrm{Fe}$ and $\mathrm{Mn}$ are difficult if traditional nutrient solutions are used. In traditional solutions the nutrient for which one wishes to induce deficiency is omitted from the solution. When the internal supply (seed) and solution contamination are exhausted, the plant becomes deficient and then becomes increasingly severely deficient until it dies. There is no "steady state" Fe or Mn stress that one could use to test the effect of another factor such as glyphosate application. The deficiency induced by omitting Fe is not at all like that caused by low phytoavailable element in soils.

Fortunately, chelator-buffering offers a method to induce relatively constant intermediate levels of $\mathrm{Fe}$ and other essential microelements stress such that interacting factors may be tested to see if they inhibit the normal plant adaptations to obtain soil Fe or Mn (Parker et al., 1995). Plants of non-Poaceae species use a combination of acidification around young roots, increased expression of a membrane bound $\mathrm{Fe}^{3+}$ chelate reductase and of a $\mathrm{Fe}^{2+}$-transporter (IRT1) to adapt to the availability of $\mathrm{Fe}$ around their young roots. Until plants can no longer up-regulate the expression of these activities to match the phytoavailability of Fe, they remain green. Chaney et al. (1992) demonstrated the use of a chelator-buffered nutrient solution to test the Festress-responses of tomato and showed that the primary responses (proton secretion, reductase and $\mathrm{Fe}^{2+}$-transporter) were up-regulated at intermediate stress before any chlorosis was evident, but when chlorosis became evident dense root hairs and more frequent lateral roots were also induced. They concluded that Fe-chlorosis induced root hairs of tomato were an effect of chlorosis rather than a plant response to obtain more Fe. During those experiments, the severity of chlorosis was maintained at intermediate levels of severity over a 10 day period at varied levels of severity from very mild to severe chlorosis.

Although the paper by Chaney et al. (1992a) illustrated the utility of such chelator-buffered solutions in study of Fe-deficiency-stress, few have used this approach at least partially because they were concerned about the high levels of CuDTPA and ZnDTPA needed to supply the activity of $\mathrm{Cu}^{2+}$ and $\mathrm{Zn}^{2+}$ required by dicots, 20 and $50 \mu \mathrm{M}$ total $\mathrm{Cu}$ and $\mathrm{Zn}$, respectively. If care is taken to limit root breakage, there is little evidence that uptake of metal chelates or free chelator is occurring, and traces of EDTA found in plants are not sufficient to interfere with element bioavailability within the plant tissues. The DTPA-buffered solutions were adapted to screen for Fe-chlorosis-resistance of soybean (Chaney et al., 1992b) and chickpea (Chaney et al., 1992c) by including bicarbonate which inhibits the ability of chlorosis susceptible species to up regulate the Fe-stressresponses to obtain Fe from wet calcareous soils.

Soybean is the crop reported to suffer adverse effects in some papers (Huber et al., 2004 and Bott et al., 2008). Because I wanted to test the effect of glyphosate on the ability of soybeans to obtain Fe and Mn, this study tests use of the chelator ethylenediaminetetraacetic acid (EDTA) to induce $\mathrm{Fe}$ and $\mathrm{Mn}$ deficiency stress to see if more acceptable test systems could be developed.

Egypt. J. Soil Sci. 53, No. 1 (2013) 


\section{Material and Methods}

Seeds of soybean (Glycine max L.Merr., cv. Williams-82) were germinated in standard germination papers wetted with 0.5 Johnson macronutrients solution under controlled conditions at $25^{\circ} \mathrm{C}$. Uniform seedlings, 6 days old, with healthy primary leaves and roots were transferred to a temperature-controlled greenhouse at $25 \pm 3^{\circ} \mathrm{C}$, to grow in continuously aerated solutions $(2.5 \mathrm{~L}$ polyethylene beakers, 6 seedlings per beaker) with a modified 0.5 Johnson solution (Johnson et al., 1957). The solution had the following composition of major nutrients: $2.5 \mathrm{mM}$ $\mathrm{Ca}\left(\mathrm{NO}_{3}\right)_{2}, 2.5 \mathrm{mM} \mathrm{KNO}{ }_{3}, 1.0 \mathrm{mM} \mathrm{MgSO}$ and $0.1 \mathrm{mM} \mathrm{KH}_{2} \mathrm{PO}_{4}$. Micronutrients were held constant/buffered with varied activities of $\mathrm{Fe}$ in all solutions. Micronutrients were added at the following total microelement concentrations $(\mu \mathrm{M}): 10 \mathrm{Mn}\left(\mathrm{MnCl}_{2}\right), 5 \mathrm{Cu}\left(\mathrm{CuSO}_{4}\right), 10 \mathrm{Zn}\left(\mathrm{ZnSO}_{4}\right), 1 \mathrm{Ni}\left(\mathrm{NiSO}_{4}, 1 \mathrm{Cd}\right.$ $\left(\mathrm{CdSO}_{4}\right)$ and $1 \mathrm{Co}\left(\mathrm{CoSO}_{4}\right)$ with equimolar EDTA plus the "excess" $100 \mu \mathrm{M}$ EDTA that provides the buffering action for all of the strongly chelated microelements. $\mathrm{H}_{3} \mathrm{BO}_{3}(10 \mu \mathrm{M}), \mathrm{Na}_{2} \mathrm{MoO}_{4}(0.1 \mu \mathrm{M})$ and $\mathrm{KCl}(100 \mu \mathrm{M})$ were included as non-chelated micronutrients. Treatments of FeEDTA were added at $0.32,1.00,3.16,5.00,10.0,20.0$ and $50.0 \mu \mathrm{M}$. A control treatment (no Fe added) was also included. In this study, ethylenediaminetetraacetic acid (EDTA) was used to buffer the free metal activity, referred to as $-\log$ free ion activity (pM). The basal concentration of EDTA in all solutions was $128 \mu \mathrm{M}$. By adding $\mathrm{Fe}$ as the FeEDTA chelate, changing $\mathrm{Fe}$ had no effect on activity of other micronutrients (Parker et al., 1995). GEOCHEM-PC was used to calculate the activities of minerals added with the buffer in all solutions. Values of $\mathrm{Fe}^{3+}$ activity $\left(\mathrm{pFe}^{3+}\right)$ and EDTA concentration in solutions treated with the above mentioned Fe concentrations are presented in Table 1.

TABLE 1. Fe and EDTA concentrations and calculated pFe in the nutrient solutions .

\begin{tabular}{lllllllll}
\hline Treatment No & $\mathbf{1}$ & $\mathbf{2}$ & $\mathbf{3}$ & $\mathbf{4}$ & $\mathbf{5}$ & $\mathbf{6}$ & $\mathbf{7}$ & $\mathbf{8}$ \\
\hline Fe $(\mu \mathrm{M})$ & 0 & 0.32 & 1.00 & 3.16 & 5.00 & 10.0 & 20.0 & 50.0 \\
\hline EDTA $(\mu \mathrm{M})$ & 128 & 128 & 129 & 131 & 133 & 138 & 148 & 178 \\
\hline Fe level $\left(\mathrm{pFe}^{3+}\right)$ & -21.88 & -21.35 & -20.89 & -20.39 & -20.19 & -19.89 & -19.59 & -19.19 \\
\hline
\end{tabular}

The activities of $\mathrm{Zn}, \mathrm{Cu}, \mathrm{Mn}, \mathrm{Ni}, \mathrm{Co}$ and $\mathrm{Cd}$ were $-10.44,-13.04,-7.84$, $13.34,-11.44$ and $-11.44 \mu \mathrm{M}$, respectively. It should be recognized that the activity of $\mathrm{Fe}^{3+}$ is not the controlled variable which induces Fe deficiency stress in dicots, but rather the competition of EDTA with IRT1 for $\mathrm{Fe}^{2+}$ generated by reduction at the young root membrane. Catalysis of $\mathrm{Fe}^{2+}$ oxidation by EDTA competes with uptake of $\mathrm{Fe}^{2+}$ by IRT1 and regenerates $\mathrm{Fe}^{3+}$ EDTA in the solution.

During the course of the experiment, additional $\mathrm{P}$ was added daily; $10 \mu \mathrm{M}$ in the first 10 days and $20 \mu \mathrm{M}$ daily until harvest. The $\mathrm{pH}$ of all solutions was adjusted to 6.5 and buffered with $2 \mathrm{mM}$ 2-[N-Morpholino]ethanesulfonic acid (MES) and adjusted every second day using solutions of $\mathrm{HCl}$ or $\mathrm{KOH}$ to keep the solution $\mathrm{pH}$ within $\pm 0.2 \mathrm{pH}$ units. Three replicates of each treatment were 
arranged in randomized blocks. Chlorosis severity was scored for the second trifoliolate leaf and younger leaves, using the scale of Weiss (1943): $1=$ full green, $2=$ light green, but no interveinal pattern, $3=$ interveinal chlorosis, $4=$ full yellow, veins light green, $5=$ severe chlorosis with necrosis.

The treatment period was terminated by removing all six plants from the beaker (day 23) and separating the shoot and root at the transition zone. Shoots (primary, first trifoliolate and stems were separated from and remaining trifoliolate leaves) and roots were transferred to paper bags and placed in a $70^{\circ} \mathrm{C}$ forced draft oven for $24 \mathrm{hr}$. The dry weight of shoots and roots was recorded. Shoots were then dry ashed overnight at $480^{\circ} \mathrm{C}$ and the ash dissolved in acids (concentrated $\mathrm{HNO}_{3}$ heated to dryness and ash dissolved in $3 \mathrm{~N} \mathrm{HCl}$ ) for analyses of nutrient composition using ICP-AES (inductively coupled plasma - atomic emission spectroscopy).

Data was subjected to analysis of variance and Tukey test was carried out using GenStat for Windows 7.0 (VSN Int. Ltd, UK, 2005). In Tables, values are means $(n=3)$ and in figures error bars are standard errors.

\section{Results}

\section{Plant Growth}

A wide range of FeEDTA concentrations was used to test soybean response to Fe nutrition. Plant growth, hereafter expressed as dry matter (DM), increased with increasing Fe supply in the solutions (Fig. 1). It was highest in the nutrient solution with $20 \mu \mathrm{M} \mathrm{Fe}\left(\mathrm{pFe}^{3+}=19.58\right)$; addition of $50 \mu \mathrm{M}$ Fe caused no further increase in plant yield. Compared to that with $20 \mu \mathrm{M} \mathrm{Fe}$, plant DM was reduced by approximately 50 and $20 \%$ in the solutions with 3.16 and $10 \mu \mathrm{M} \mathrm{Fe}$, respectively.

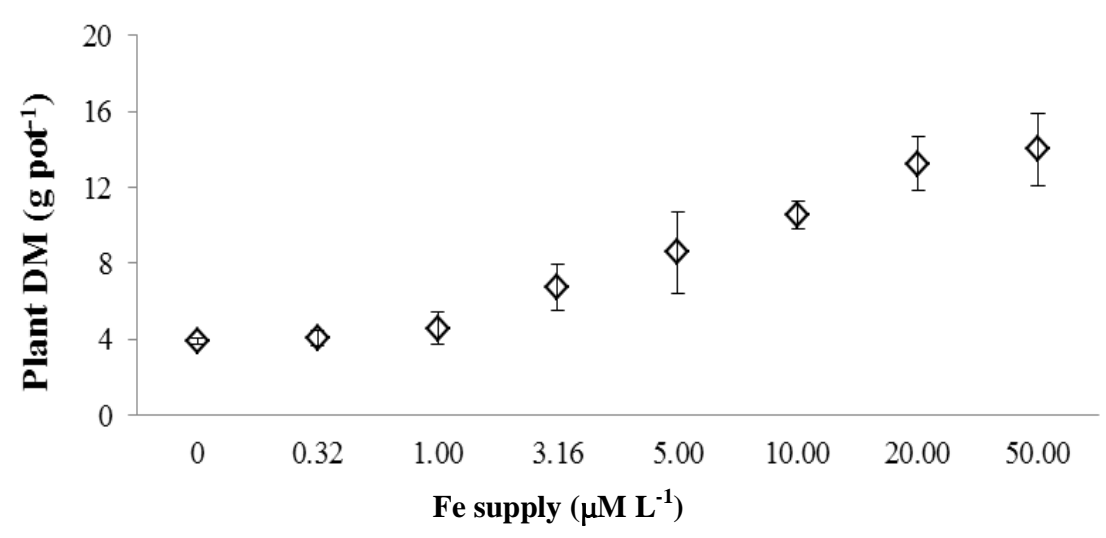

Fig. 1. Soybean dry matter $\left(\mathrm{g} \mathrm{pot}^{-1}\right)$ after 23 days of growth in the nutrient solutions with varied total FeEDTA supply $0.0,20.0$ and $50.0 \mu \mathrm{M} \mathrm{L}^{-1}$.

Egypt. J. Soil Sci. 53, No. 1 (2013) 


\section{Trifoliate nutrient composition and chlorosis severity}

Table 2 presents the nutrient composition and chlorosis score of the second and younger trifoliate leaves of soybean (the composition of first trifoliolate leaves is more strongly affected by seed supplies than are younger leaves, so the nutrient levels in younger trifoliolates are used to indicate nutritional status related to treatments).

The concentration of Fe correlated closely with FeEDTA/pFe ${ }^{3+}$ in the solution; $\mathrm{Fe}$ concentration in leaves increased with increasing $\mathrm{Fe}$ concentration in solution, but addition of more than $20 \mu \mathrm{M}$ had no additional effect. Concentrations of $\mathrm{P}, \mathrm{K}, \mathrm{Ca}$, $\mathrm{Mn}, \mathrm{Mo}, \mathrm{Ni}$ and $\mathrm{Cd}$ were at the optimal concentration with the higher $\mathrm{Fe}$ supply, whereas in the solutions without (no Fe added), or with lower Fe, most nutrients were higher due to the lower biomass production under Fe deficiency. Total solution $\mathrm{Fe}$ had no effect on soybean uptake of $\mathrm{Mg}, \mathrm{Zn}$ or $\mathrm{Cu}$.

The soybean plants remained green until the end of growth of the first trifoliolate leaves due to the seed Fe supply. Soybean second trifoliate leaves started to show chlorosis on day 9 after transplanting. Thereafter, severity of chlorosis of the second and younger trifoliolate leaves was closely related to the amount of FeEDTA supplied. Over time, the leaves with 0 and $0.32 \mu \mathrm{M}$ FeEDTA became severely chlorotic. At intermediate levels (1-10 $\mu \mathrm{M}$ FeEDTA) leaves showed intermediate severity of chlorosis; the plants kept growing and remained mildly or moderately chlorotic during the remaining growth. Chlorosis score of soybean leaves with $20 \mu \mathrm{M}$ was insignificantly different from that with $50 \mu \mathrm{M}$ FeEDTA.

TABLE 2. Nutrient composition and chlorosis score of the second and younger trifoliolate leaves of soybean grown in solutions with EDTA-buffered Fe supplied at $0,0.32,1.00,3.16,5.00,10.0,20.0$ and $50.0 \mu M L^{-1}$.

\begin{tabular}{|c|c|c|c|c|c|c|c|c|c|c|c|c|}
\hline FeEDTA & $\mathbf{P}$ & $\mathbf{K}$ & $\mathrm{Ca}$ & Mg & $\mathbf{F e}$ & Zn & Mn & $\mathbf{C u}$ & Mo & $\mathbf{N i}$ & Cd & $\begin{array}{c}\text { Chloros } \\
\text { is } \\
\text { score* }\end{array}$ \\
\hline$\mu \mathbf{M}$ & \multicolumn{4}{|c|}{ 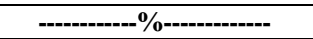 } & \multicolumn{7}{|c|}{--------------mg kg-1 DM----------- } & \\
\hline 0.00 & $0.89 f$ & $4.7 \mathrm{a}$ & $1.67 \mathrm{a}$ & $0.36 \mathrm{c}$ & $15 \mathrm{a}$ & $55 b$ & $282 \mathrm{a}$ & $9.6 \mathrm{e}$ & $4.0 \mathrm{f}$ & $1.8 \mathrm{~d}$ & $0.60 \mathrm{~d}$ & $5.0 \mathrm{f}$ \\
\hline 0.32 & $1.01 \mathrm{f}$ & $4.6 \mathrm{a}$ & $1.66 \mathrm{a}$ & $0.39 \mathrm{~d}$ & $13 \mathrm{a}$ & $62 d$ & $286 a$ & $11.2 \mathrm{e}$ & $3.7 \mathrm{e}$ & $1.6 \mathrm{~d}$ & $0.64 \mathrm{e}$ & $4.6 f$ \\
\hline 1.00 & $0.70 \mathrm{e}$ & $5.5 \mathrm{~b}$ & $1.69 \mathrm{a}$ & $0.33 \mathrm{bc}$ & $27 b$ & $51 b$ & $285 \mathrm{a}$ & $7.8 \mathrm{~d}$ & $2.8 \mathrm{~d}$ & $1.3 \mathrm{c}$ & $0.77 \mathrm{f}$ & $3.6 \mathrm{e}$ \\
\hline 3.16 & $0.53 d$ & $4.7 \mathrm{a}$ & $1.76 \mathrm{ab}$ & $0.30 \mathrm{~b}$ & $34 c$ & $48 b$ & $215 b$ & $4.5 \mathrm{c}$ & $1.7 \mathrm{c}$ & $1.3 \mathrm{c}$ & $0.70 \mathrm{f}$ & 3.0de \\
\hline 5.00 & $0.39 \mathrm{c}$ & $4.3 \mathrm{a}$ & $1.83 \mathrm{~b}$ & $0.31 b$ & $42 d$ & $38 \mathrm{c}$ & $161 \mathrm{c}$ & $5.6 \mathrm{~b}$ & $1.5 \mathrm{bc}$ & $0.9 b$ & $0.59 \mathrm{~d}$ & $2.5 \mathrm{c}$ \\
\hline 10.0 & $0.39 \mathrm{c}$ & $3.1 \mathrm{c}$ & $1.66 \mathrm{a}$ & $0.36 \mathrm{c}$ & $58 \mathrm{e}$ & $47 b$ & $128 \mathrm{~d}$ & $7.4 \mathrm{~d}$ & $1.3 b$ & $1.0 \mathrm{~b}$ & $0.44 \mathrm{c}$ & $2.0 \mathrm{~b}$ \\
\hline 20.0 & $0.34 b$ & $4.6 \mathrm{a}$ & $1.33 \mathrm{c}$ & $0.31 b$ & $88 \mathrm{f}$ & $49 b$ & $81 \mathrm{e}$ & $5.0 \mathrm{~b}$ & $0.7 \mathrm{a}$ & $0.6 \mathrm{a}$ & $0.30 \mathrm{~b}$ & $1.5 \mathrm{a}$ \\
\hline 50.0 & $0.29 \mathrm{a}$ & $2.9 \mathrm{c}$ & $1.07 \mathrm{~d}$ & $0.26 \mathrm{a}$ & $85 f$ & $34 \mathrm{a}$ & $89 \mathrm{e}$ & $3.2 \mathrm{a}$ & $0.7 \mathrm{a}$ & $0.6 \mathrm{a}$ & $0.23 \mathrm{a}$ & $1.5 \mathrm{a}$ \\
\hline
\end{tabular}

* Chlorosis score is an average of visual rating of second and younger trifoliolate leaves of 6 plants per beaker on days $9,15,18$ and 21 after transplanting .

\section{Discussion}

In contrast with traditional nutrient solutions, using EDTA buffered solutions can supply varied levels of Fe stress, which remains relatively constant over time. This varied severity has the appearance of the varied severity of chlorosis one sees in the field with varied phytoavailability of soil Fe due to varied bicarbonate or inactive $\mathrm{Fe}$ oxides in calcareous soils. In most field observations, soybean

Egypt. J. Soil Sci. 53, No. 1 (2013) 
chlorosis severity varies across the field from green to mild to moderate to severe chlorosis depending on soil chemistry and water content.

The EDTA buffered nutrient solution system allows one to supply strongly buffered adequate levels of the other micronutrient cations ( $\mathrm{Zn}, \mathrm{Cu}, \mathrm{Mn}, \mathrm{Ni}, \mathrm{Co}$ ) and control levels of other cations such as $\mathrm{Cd}$. Buffering also prevents other chelatable elements from displacing Fe from the FeEDTA as occurs in traditional nutrient solutions (Parker et al., 1995). These elements are buffered at activities that allow the plant to obtain normal levels for growth with a constant supply over time rather than the higher supply when solutions are renewed in traditional solution culture. As indicated in the work of Chaney et al. (1992a), using buffered $\mathrm{Fe}^{3+}$ supply allows plants to express their inherent Fe-stress-responses while remaining green as occurs in normal soils. And if study of physiological changes in response to chlorosis is desired, lower Fe availability can be supplied to induce steady severity of chlorosis rather than simply letting the plant run out of $\mathrm{Fe}$ and move toward death. Because much lower levels of buffered total $\mathrm{Zn}$ and $\mathrm{Cu}$ are required in EDTA buffered solutions, concerns raised by the DTPAbuffered system of Chaney et al. (1992a,b, c) may be avoided. As long as the nutrient solution is kept in the dark to avoid photo-decomposition of the FeEDTA, the buffering will remain steady during growth. It is still reasonable to replace solutions periodically during longer growth periods. In all cases, when a micronutrient cation is supplied by seeds, deficiency cannot be induced until the seed supply is diluted by growth.

It could be concluded that EDTA-buffered Johnson solution offers a strong control of Fe stress at varied severity and should provide a valuable tool in study of microelement plant nutrition.

\section{References}

Bernards, M.L., Thelen, K.D. and Penner, D. (2005) Glyphosate efficacy is antagonized by manganese. Weed Technol. 19: 27-34.

Bott, S., Tesfamariam, T., Candan, H., Cakmak, I., Römheld, V., Neumann, G., Jones, D.L., George, T.S., Hodge, A., Marschner, P. and Hinsinger, P. (2008) Glyphosate-induced impairment of plant growth and micronutrient status in glyphosate-resistant soybean (Glycine max L.). Plant Soil 312: 185-194.

Chaney, R.L., Chen, Y., Green, C.E., Holden, M.J., Bell, P.F. and Luster, D.G. (1992a) Root hairs on chlorotic tomatoes are an effect of chlorosis rather than part of the adaptive Fe-stress-response. J. Plant Nutr. 15: 1857-1875.

Chaney, R.L., Coulombe, B.A., Bell, P.F. and Angle, J.S. (1992b) Detailed method to screen dicot cultivars for resistance to Fe-chlorosis using FeDTPA and bicarbonate in nutrient solutions. J. Plant Nutr. 15: 2063-2083.

Chaney, R.L., Hamze, M.H. and Bell, P.F. (1992c) Screening chickpea for iron chlorosis resistance using bicarbonate in nutrient solution to simulate calcareous soils. J. Plant Nutr. 15: 2045-2062.

Egypt. J. Soil Sci. 53, No. 1 (2013) 
Duke, S.O., Lydon, J., Koskinen, W.C., Moorman, T.B., Chaney, R.L. and Hammerschmidt, R. (2012) Glyphosate effects on plant mineral nutrition, crop rhizosphere microbiota, and plant disease in glyphosate-resistant crops. J. Agric. Food Chem. 60: 6764-6771

Ebelhar, S.A., Varsa, E.C. and Hart, C.D. (2006) Soil pH and manganese effects on yield of Roundup Ready® soybeans. IL Fert. Conf. Proc. 54-65.

Eker, S., Ozturk, L., Yazici, A., Erenoglu, B., Römheld, V. and Cakmak, I. (2006) Foliar-applied glyphosate substantially reduced uptake and transport of iron and manganese in sunflower (Helianthus annuus L.) plants. J. Agric. Food Chem. 54: 10018-10025.

Huber, D.M. (2007) What about glyphosate-induced manganese deficiency? Fluid J. 15 (Fall): 20-22.

Huber, D.M., Leuck, J.D., Smith, W.C. and Christmas, E.P. (2004) Induced manganese deficiency in GM soybeans. Proc. North Central Ext.-Ind. Fert. Conf. 20: 80-83.

Johnson, C.M., Stout, P.R., Broyer, T.C. and Carltonm, A.B. (1957) Comparative chlorine requirements of different plant species. Plant Soil 8: 337-353.

Ozturk, L., Yazici, A., Eker, S., Gokmen, O., Römheld, V. and Cakmak, I. (2008) Glyphosate inhibition of ferric reductase activity in iron deficient sunflower roots. New Phytol. 177: 899-906.

Parker, D.R., Chaney, R.L. and Norvell, W.A. (1995) Equilibrium computer models: Applications to plant nutrition research. In: "Chemical Equilibrium and Reaction Models", R.H. Loeppert, A.P. Schwab and S. Goldberg (Ed.), pp. 163 -200, Soil Science Society of America Special Publ. No. 42, Soil Sci. Soc. Am./Am. Soc. Agron., Madison, WI.

Weiss, M.G. (1943) Inheritance and physiology of efficiency of iron utilization by soybean. Genetics 28: 253-268.

(Received 6/2/2013;

accepted 28/2/2013) 


\title{
الحكم فى ظاهرة الإصفرار الناتج عن نقص الحديد فى نبات فول
}

Fe EDTA الصويا بإستخدام محاليل فن الاصنيل

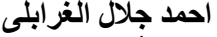 \\ قسم الأر اضى والمياه - كلية الزراعة - جامعة اسيوط - أسيوط - مصر.
}

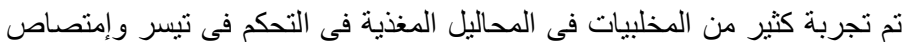

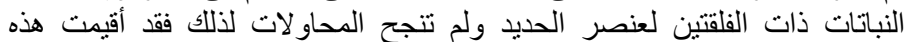

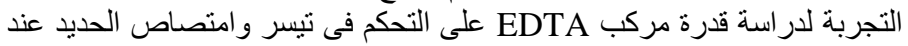

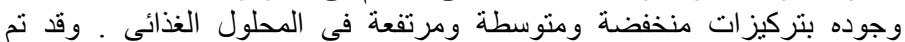

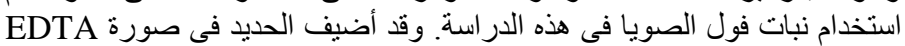

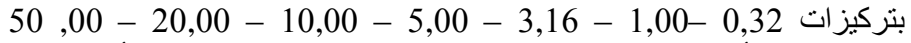
ميكرومول بالأضافة إلى معاملة الكنترول مع إضافة 100 ميكرومول أضافئ الفية من EDTA

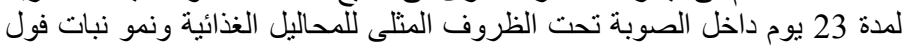
الصويا.
\end{abstract}

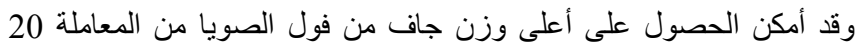

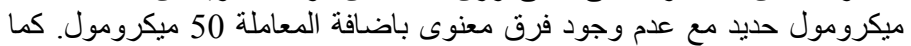

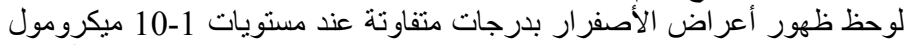
FeEDTA

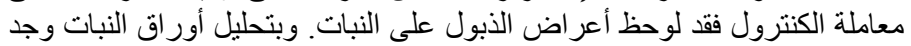

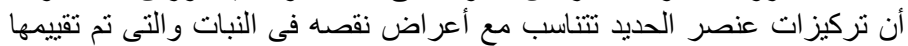
من خلال تقييم درجة الإصفرار فيما كان تركيز بقية العناصر الصغرى في التئ الحدود

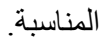

ومن النتائج أتضح أن مركب EDTA كمادة منظمة فى الدحاليل الغذائية لها

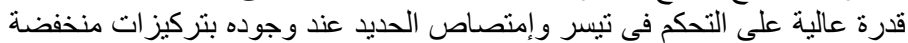

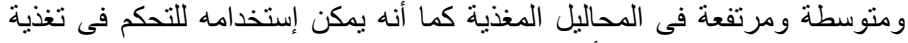

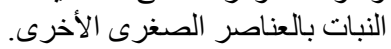

